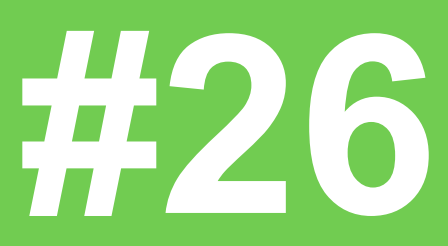

\title{
MEMÓRIA SOBRE ESTILHAÇOS DE BOMBAS EM BARCELONA
}

\section{Daniel Carlos Santos da Silva}

Universidade de São Paulo

https://orcid.org/0000-0001-5294-3631

Artículo || Recibido: 12/06/2021 | Aceptado: 29/11/2021 | Publicado: 01/2022 DOI 10.1344/452f.2022.26.8 dan.silva58@hotmail.com

Ilustración || Laura Castanedo - Todos los derechos reservados Corrección || Lívia Lemos Duarte (liviaduarte2008@gmail.com)

Texto || @ Daniel Carlos Santos da Silva - Licencia: Atribución-NoComercial-SinDerivadas 4.0 Internacional de Creative Commons

\section{(c) (1) $(9)$}



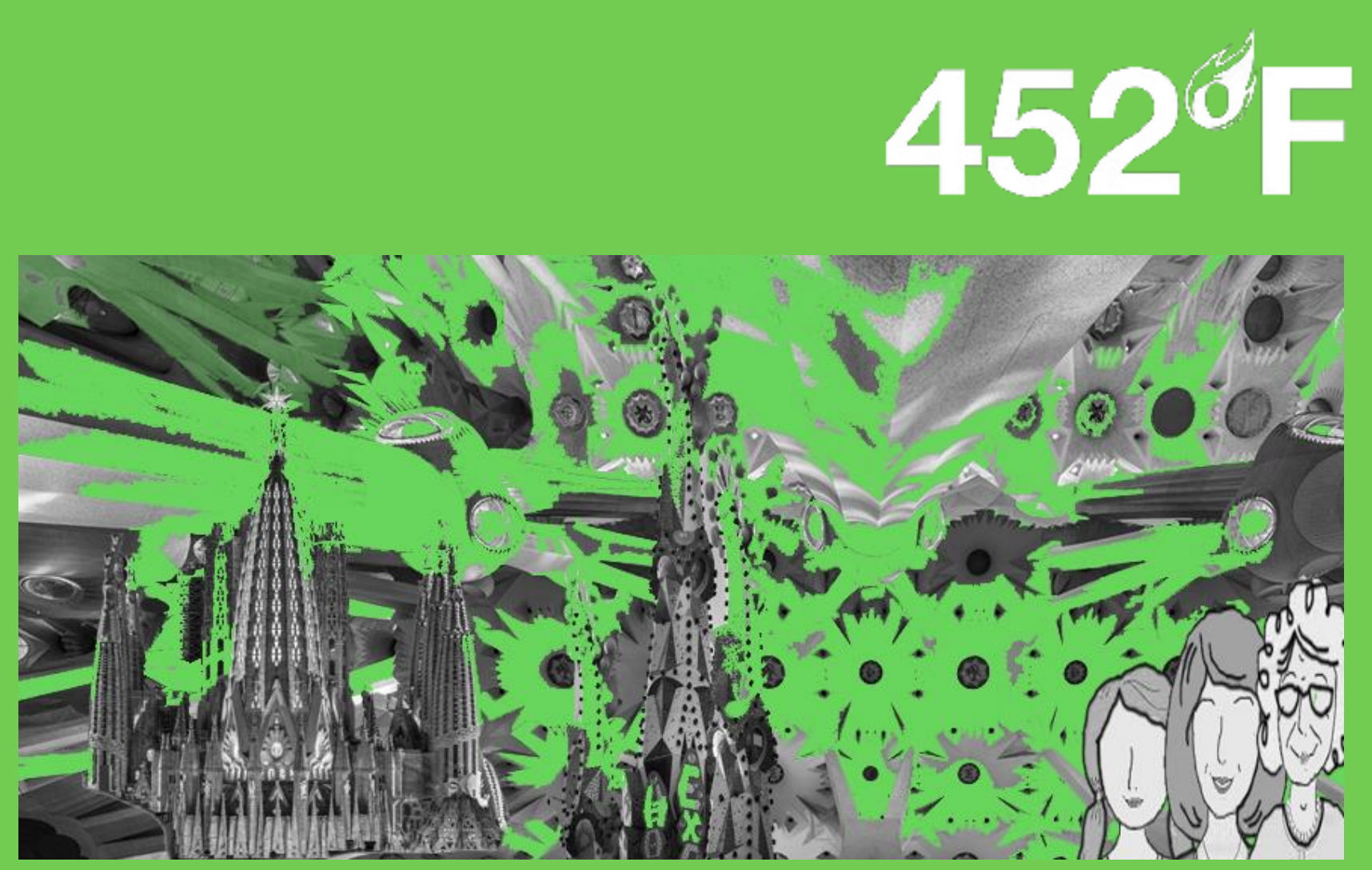

Resumo || Esse artigo objetiva analisar a construção cronotópica de Ramona, adiós (1972), de Montserrat Roig, com vistas à discussão do processo de exílio decorrente da ditadura franquista. Para tanto, compreendo-o também como condição para os que permaneceram em território espanhol durante o franquismo, remetendo-me à noção impressa no romance de Miguel Salabert: El exilio interior. Analisarei passagens da obra de Roig nas quais as três protagonistas caminham pelas ruas de Barcelona em distintos períodos, considerando que esse percurso analítico pode lançar luz sobre o cotidiano de sujeitos sufocados durante e em um tempo-espaço de exceção.

\section{Palavras-chave || Montserrat Roig | Ramona, adiós | Cronotopo | Exílio interior}

Resumen || El presente artículo tiene como objetivo analizar la construcción del cronotopo en Ramona, adiós (1972) de Monterrat Roig como medio para discutir el proceso de exilio derivado de la dictadura franquista. Para ello, asumo la posibilidad de entender el exilio como una condición en la que se encontraban las personas que permanecieron en España durante el franquismo, tal y como propone la novela El exilio interior de Miguel Salabert. Examinaré fragmentos de la obra de Roig en los que los tres protagonistas deambulan por las calles de Barcelona en diferentes épocas, creyendo que este método de análisis podría revelar la vida cotidiana de las personas asfixiadas durante y en un tiempo-espacio de excepción.

\section{Palabras clave || Montserrat Roig | Ramona, adiós | Cronotopo | Exilio interior}

Abstract || The present article aims to analyze the construction of the chronotope in Monterrat Roig's Ramona, adiós (1972) as a means of discussing the process of exile resulting from the Francoist dictatorship. In order to do so, I assume the possibility of understanding exile as a condition in which people who stayed in Spain during Franco's regime found themselves, as proposed in the novel El exilio interior by Miguel Salabert. I will examine fragments of Roig's work in which the three protagonists wander through the streets of Barcelona in different periods of time, believing this analytical method might disclose the daily life of persons suffocated during and in a time-space of exception.

\section{Keywords || Montserrat Roig | Ramona, adiós | Chronotope | Internal exile}

Resum || El present article té com a objectiu analitzar la construcció del cronotop en Ramona, adiós (1972) de Monterrat Roig per a discutir el procés d'exili derivat de la dictadura franquista. Per a això, assumeixo la possibilitat d'entendre l'exili com una condició en la qual es troben els que es van quedar a Espanya durant el franquisme, com proposa la novel-la Miguel Salabert El exilio interior. Examinaré fragments de l'obra de Roig en els quals els tres protagonistes deambulen pels carrers de Barcelona en diferents períodes de temps, creient que aquest mètode analític podria revelar la vida quotidiana d'aquelles persones asfixiades durant $i$ en un espai-temps d'excepció.

Paraules clau || Montserrat Roig | Ramona, adiós | Cronotop | Exili interior 


\section{Introdução}

Montserrat Roig (1946-1991) é uma escritora catalã de fundamental importância para a literatura espanhola contemporânea, posto que, através de sua obra, é possível refletir sobre a representação do complexo contexto da Espanha do século XX. Nas suas composições ficcionais, fica plasmado o percurso de personagens que buscam sobreviver a um tempo-espaço de exceção. Isso remete a uma política de censura e, portanto, a asfixia que elide ao sujeito o direito de ir e vir: a sua liberdade. Como conjuntura que isso representa, é possível destacar o período compreendido entre 1939 e 1975, assinalado pela ditadura consequente da Guerra Civil Espanhola (1936-1939).

Tal momento de inflexão está presente no processo de produção dessa autora, tanto por desenvolver seus escritos durante o regime ditatorial, quanto por situar suas narrativas em torno desse tempo, o que particulariza suas tramas por conta de uma série de desdobramentos que convergem para a situação de sufocamento decorrente das perseguições que tomam conta da Espanha.

O acosso remonta dos enfrentamentos bélicos no país, de modo que houve debandada já na iminência do revés para os nacionalistas. Por um lado, parte dos derrotados permanece em sua pátria sob a vigilância dos que tomam o poder, outros republicanos são perseguidos com base na Ley de Responsabilidades políticas, publicada em 13 de fevereiro de 1930, por haver participado "en la vida política republicana, o que, desde febrero de 1936, se habían opuesto al "Movimiento" nacional: "por actos concretos o pasividad grave"» (Vilar, 1986: 26). Por outro lado, há uma série de fugas que em grande parte se dão através da fronteira com a França ou se concretiza o trágico destino daqueles que foram levados aos campos de concentração. Nos casos dos espanhóis que atravessam a fronteira, o processo de exílio se intensifica antes mesmo do fim da guerra, em abril de 1939. Contudo, o que ocorre com os que permaneceram no país?

Entre as mudanças concernentes à homogeneização preconizada pelo regime autoritário, uma delas diz respeito diretamente à formação identitária de Roig, a questão do uso da língua: «Em 21 de maio, o castelhano foi declarado único idioma oficial e proibiu-se o uso de basco ou catalão em público» (Beevor, 2006: 473). Essa sentença de controle sobre as regiões autônomas da Espanha pode ser considerada, portanto, um vértice do franquismo, posto que, já na formação do seu primeiro governo, em 30 de janeiro de 1938, uma das manifestações mais primárias de parte daqueles que vivem em território espanhol é posta em xeque: a expressão oral e escrita ${ }^{1}$. Assinalo, então, desde aqui, o que pode ser notado como posição de embate da escritora catalã que, mesmo iniciando suas publicações durante o chamado tardofranquismo, ressalta na escritura desenvolvida em língua catalã seu posicionamento pela liberdade de expressão.

A sua manifestação linguística, portanto, é decisiva a uma prática de marcação de existências por vezes invisibilizadas. Cabe salientar que Montserrat Roig, para além de sua contundente obra literária composta até 
os momentos finais de sua vida -interrompida em 1991 em virtude de um câncer de mama, quando ela contava com 45 anos - encabeça outros modos de comunicação, como o programa Personatges veiculado pela TVE, no biênio 1977-1978, em que ela entrevista 49 personalidades catalãs. Ou seja, uma marca protuberante da reivindicação de sua identidade e consequente contribuição para a divulgação de sua língua, banida até anos anteriores. Soma-se a isso o seu trabalho jornalístico e de viés testemunhal, que nos dá um parâmetro ainda maior do entrecruzamento entre a identidade catalã e o processo de exílio dos republicanos após o fim da Guerra Civil. Sua obra Los catalanes en Ios campos nazis, construída a partir da primeira metade dos anos de 1970, compila uma série de pesquisas e testemunhos de 50 catalães deportados entre os anos de 1938 e 1945 nos campos de concentração nazistas. A versão em catalão, publicada em 1977 —um ano antes da versão espanhola - ganha o prêmio «Crítica Serra D'Or» de melhor reportagem já no ano de seu lançamento. Todos esses dados ilustram em alguma medida o lugar de Roig não somente na história da literatura espanhola, mas também sua posição enquanto mulher e intelectual catalã que, apesar de viver sua infância e juventude sob um regime de exceção, tem toda uma formação enraizada no direito à diversidade e à existência de formas distintas de manifestação do pensamento crítico.

Por vezes, seu trabalho jornalístico caminha em paralelo ao de narradora. A produção de Los catalanes en los campos nazis se intersecciona temporalmente com a publicação de Ramona, adiós em 1972. É o primeiro romance da trilogia sucedida por Tiempo de cerezas (1977) e La hora violeta (1980) na qual se arquiteta ficcionalmente o processo da memória que se ramifica e se fragmenta em torno do contexto bélico vivido pelas famílias Miralpeix e Ventura-Claret. Já seu romance de estreia permite a discussão sobre a Guerra Civil Espanhola, bem como as consequências desse trágico momento.

No entanto, outro questionamento se faz indispensável para refletir sobre a questão do exílio assinalada neste trabalho. Se em narrativas, Roig retrata personagens que vivem em Barcelona, de que maneira é possível discutir o desterro? Em primeira instância, porque a própria manifestação da memória que conforma a composição da autora se estabelece por meio de ausências. Nas tramas, há tanto o retorno de personagens à capital catalã, como a busca por outras que não estão presentes fisicamente, seja por haver se deslocado a outros espaços ou já não estarem vivas e, portanto, presentificadas pela lembrança. Nesse sentido, estamos diante de uma discussão que perpassa toda uma esfera simbólica.

O diálogo possível de Ramona, adiós com a novelística do exílio sobre a guerra civil se dá, dessa maneira, por representar a vivência principalmente daquelas que permanecem em território espanhol, mas nem por isso deixam de vivenciar uma forma de desterro: primeiramente por serem mulheres, apartadas da decisão histórica que dá ao homem o poder de conduzi-las; em segundo lugar, por constituírem uma identidade catalã controlada pelo intento autoritário de homogeneização; por fim, porque considero que o sufocamento dos que vivem sob os mandos e desmandos 
ditatoriais assinala para um modo de não pertencimento, o que bem pode iluminar a reflexão sobre a contenda e o decorrente desterro.

Portanto, nesse primeiro romance de Roig, a guerra e as suas consequências estão assinaladas como circunstâncias cerceadoras da liberdade. O anseio por esse direito de emancipação do sujeito é o que se sobressai como condição humana dessa história, por meio da palavra escrita e manifestada por figuras femininas e consequentemente subalternas ou, como diria Carmen Martín Gaite em Usos amorosos de la posguerra española, pela «muy mujer»: a figura da mulher projetada pela Espanha nacionalista, caracterizada por sua «actitud pasiva y espírito de sacrificio» (Martín Gaite, 1994: 19)². Em suma, apresenta-se na narrativa da escritora catalã personagens inseridas numa sociedade autoritária e patriarcal que, direta ou indiretamente, demonstram um movimento de resistência veiculado pela centralidade da mulher num mundo em ruínas.

A fim de esclarecer a proposição de análise do volume, irei apresentá-lo em linhas gerais: avó, mãe e filha, todas nomeadas Mundeta —que advém do nome Ramona que dá título à obra - têm suas vidas narradas de maneira fragmentária, desde o período anterior à contenda, até o momento antecedente à escritura da obra, qual seja, os anos finais do franquismo. A avó é a narradora de sua própria história de fim do século XIX e início do século XX por meio da escritura de seu diário, que encabeça a sequência narrativa ao longo da trama; a mãe relata no prefácio e no posfácio sua experiência enquanto cidadã exposta aos bombardeios que assolam Barcelona durante a Guerra Civil, ao passo que, no desenvolvimento do romance, uma voz narrativa em terceira pessoa conta sobre fatos vividos pela protagonista; a filha, última geração da família de mulheres representadas, tem também momentos de sua vida contados por uma voz narrativa onisciente, que situam a personagem enquanto estudante universitária e jovem dos anos de 1960. O espaço narrativo se constitui como elemento estrutural expressivo, já que ele compõe a significação da grande consequência bélica: o abafamento das vozes e a tentativa de impor uma forma homogênea de expressá-las. Por esse viés, compreendo que o pensamento posto em palavras no romance através das protagonistas que o conformam se funde à construção espacial que revela a ideia de banimento também daqueles que permaneceram em território espanhol durante o período de exceção. Isso ocorre na obra por meio da representação da decadência do sujeito diante de seu entorno e de seu resultante e relativo antagonismo à sociedade constituída no pós-guerra.

A partir dessas considerações, é possível afirmar que Barcelona deixa de ser somente um lugar quando escrito no papel da criação narrativa para converter-se em ambientação desde o momento em que a cidade passa a ser observada através de uma perspectiva literária que toma a capital catalã como espaço de ação das histórias narradas. Ramona, adiós concede ao leitor representações de Barcelona, reconstruída narrativamente por meio dos espaços interiores e exteriores em que as protagonistas das tramas transitam. São elas também extensões do espaço narrativo, posto que o olhar que lançam sobre seu entorno reflete não somente seus respectivos modos de ver o mundo, mas as figurações das personagens também passam a constituir o próprio universo ficcionalizado. 


\title{
1. Bombas
}

Pensada desde um prisma não estático, a cidade pode ser considerada em seu sentido orgânico também pela relação existente com o tempo do romance. Ramona, adiós foi publicado no período de exceção que tomou conta da Espanha entre 1939 e 1975 durante o franquismo. Contudo, materializa momentos anteriores à Guerra Civil Espanhola, perfazendo o momento bélico e representando suas catástrofes. Há, portanto, um processo da memória na escritura do romance que traz à tona a retomada de um tempo atroz:

\begin{abstract}
Buscamos aquilo que tememos ter esquecido, provisoriamente ou para sempre, com base na experiência ordinária da recordação, sem que possamos decidir entre duas hipóteses a respeito da origem do esquecimento: trata-se de um apagamento definitivo dos rastros do que foi aprendido anteriormente, ou de um impedimento provisório, este mesmo eventualmente superável, oposto à sua reanimação? Essa incerteza quanto à natureza profunda do esquecimento dá à busca o seu colorido inquieto. Quem busca não encontra necessariamente. O esforço da recordação pode ter sucesso ou fracassar (Ricœur, 2007: 46).
\end{abstract}

Paul Ricœur assinala uma dúvida sobre a «origem do esquecimento» que pode trazer à tona a noção sobre o trauma, justamente quando aponta para o «apagamento dos rastros» como uma das hipóteses para a memória contingenciada. Dessa maneira, o sujeito, agredido psicologicamente por uma experiência violenta, pode não recordar seu passado pelo próprio processo intrincado da lembrança que se distancia do momento de perturbação. É o que, em certa medida, relaciona-se com as inúmeras vítimas dos campos de concentração de Auschwitz e que são apresentadas no testemunho de Primo Levi, escrito em Si esto es un hombre: «[Charles] me habló de Arthur, que vive en un pueblo muy alejado, está viejo y enfermo y no desea recibir visitas que puedan despertarle viejas angustias" (Levi, 2013: 209). Na edição de 2013 —traduzida ao espanhol- da obra do escritor italiano, ele escreve um apêndice em que responde a perguntas muito recorrentes sobre sua experiência como vítima do nazismo. Arthur, que havia sido um de seus companheiros nos meses de horror vivenciados em regime concentracionário, passa a viver anos mais tarde numa região isolada, e o fato de rejeitar visitas se dá por conta de sua memória adormecida que, decididamente por Arthur, não é despertada. Seu trauma, então, pode ser considerado motivo de seu esquecimento, ao passo que deseja não lembrar, mas não pode, posto que para ele é infactível esquecer.

De outro modo, é também possível retomar posicionamentos opressivos que, para impedirem que venham à tona as lembranças do tempo de sufocamento que preconizam, precisamente apagam os rastros, impedindo a memória e corroborando para o esquecimento. Isso permite pensar a censura como mecanismo de repressão característico de um regime autoritário, tal qual aquele que se impôs na Espanha durante a ditadura. Assim sendo, a tensão entre «um apagamento definitivo dos rastros» $\mathrm{e}$ «um impedimento provisório" que assinalam o esquecimento é a tônica para os interditos e fragmentos que conformam o romance de Roig. Ou ainda, num questionamento, o que o "colorido inquieto» da memória das personagens 
e vozes narrativas é capaz de revelar, a partir da dimensão cronotópica, sobre o próprio tempo e espaço ficcionalizados?

É nesse sentido que tais elementos narrativos são considerados centrais para a análise da obra. Pensá-los é possível somente se pressupomos o caráter dinâmico de referidos aspectos estruturantes, e é com base no lugar da ficção que compreendo a mobilidade implicada na composição das narrativas: «A análise do movimento a partir dos movimentos na (da) literatura exemplifica perfeitamente em que medida fundamental se formam espaços somente mediante movimentos, mediante motions e emoticons» (Ette, 2015: 287).

Desse modo, as Mundetas — filha, mãe e avó-, personagens centrais de Ramona, adiós, lançam seu olhar sobre um lugar e um tempo sufocados. Seja como narradoras, seja a partir de uma voz narrativa que as observa e dá vida. E é no caminho que percorrem que encontro o alicerce para a proposta de reflexão sobre as obras:

Ora, o essencial da representação literária do espaço não residirá precisamente na construção de um universo imaginário o qual deriva do ponto de vista de um sujeito e de uma composição de texto? Ainda que não seja necessário negligenciar a contribuição do referente geográfico, do contexto e do intertexto, a representação literária é uma «ego-geografia e uma «composição de lugar», uma construção semântica e formal singular, que supõe, para ser compreendida, o ponto de vista de um outro sujeito, isto é, uma leitura crítica (Collot, 2012: 8).

«O ponto de vista do sujeito», mencionado por Collot, se faz essencial para o trabalho de análise, de modo que Barcelona irá se conformando por diferentes matizes, dependendo de qual olhar está sendo lançado sobre ela. O que se intersecciona nessas perspectivas do romance diz respeito à visão de mulheres que, apesar da posição subalterna imposta a elas no contexto em que se situam, assumem centralidade na trama e nos permitem questionar a posição de sujeitos que caminham por entre escombros de guerra. Assim sendo, reitero que essas figuras femininas são extensões do espaço literário construído, ao passo que tais espaços são ressignificados a cada novo olhar que sobre eles são lançados. Ou ainda: são elas, as mulheres, que (re)constroem o espaço; são seus olhares que propiciam a ressignificação espacial e consequente ambientação plasmada nas obras.

Refletir, assim, com base na geocrítica, é considerar a organicidade espacial a partir das perspectivas das personagens sobre os caminhos que percorrem. Como, então, Barcelona é vista e composta nos romances em meio aos desastres que conformam o tempo de guerra?

Há um movimento assinalado fragmentariamente nas tramas —posto que plasmado pela irregularidade da memória- que implica a reflexão sobre a conjuntura em torno da contenda e, portanto, do que dela advém: o autoritarismo, a devastação e o cerceamento como processo ditatorial representado.

Considero que a coerção se conforma desde a articulação da guerra que põe em xeque a permanência legítima da Segunda República Espanhola. 
No entanto, é ao longo da Guerra Civil que o autoritarismo se institui, dando sequência à devastação das vidas inseridas no contexto bélico. A partir de então, a repressão assola a Espanha não somente pelas mortes causadas durante a contenda, mas pelas que se seguem como punição aos divergentes do novo regime - $\mathrm{O}$ autoritário- e pelas implicações dele decorrentes, o que se converte na coibição de vozes.

Com isso, compreendo que o espaço construído nos romances deflagra uma representação contundente do sufocamento do tempo vivido e configurado literariamente. Empresto, para tanto, a expressão cunhada por Miguel Salabert que intitula sua obra literária de 1988 e considero que, se houve um êxodo espanhol resultante da guerra, para os que se mantiveram em território nacional tampouco houve estabilidade, mas sim El exílio interior. Portanto, as personagens como representações de vidas imersas no autoritarismo assinalam para uma consequência inerente do franquismo: a vida — sufocada pela ditadura— é uma forma de exílio.

Não obstante, faz-se necessário estabelecer uma diferenciação de ordem semântica do termo "exílio", posto que ele indica um distanciamento espacial e não poderia corresponder literalmente às vidas retratadas no romance que aqui discuto. Para desenvolver a noção de desterro que proponho, ressalto a relação que esse processo mantém com o aspecto político:

com o nacional-socialismo, a resposta à pergunta «Quem é e o que é alemão?» (e por consequência também: «Quem é e quem não o é?») coincide sem mais com a tarefa política suprema. Fascismo e nazismo são, sobretudo, uma redefinição das relações entre o homem e o cidadão e, por mais que isso possa parecer paradoxal, somente podem ser completamente compreendidos se forem situadas no panorama biopolítico inaugurado pela soberania nacional e pelas Declarações de Direitos (Danner, 2013: 39).

Tendo em vista que o período de exceção da Espanha tem como marca a repressão aos republicanos, visível por si só na debandada que ocorre no país em torno do fim da contenda, cabe então uma reformulação da pergunta destacada acima: quem é e o que é espanhol? Com a ascensão do fascismo, a questão de naturalidade e de pertencimento é relativizada e circunscrita aos que apoiam quem está no poder. Ora, não basta nascer em território nacional para dele fazer parte enquanto cidadão quando se cria uma dinâmica de autenticidade ou de suposto merecimento de pertencer ao Estado fascista-segregador, visto que os divergentes são categoricamente apartados. Isso posto, é então possível ampliar a discussão referente ao exílio decorrente de imposições políticas, pois, mesmo que haja desacordo da governabilidade vigente e, no entanto, se permaneça em território nacional, há um sintoma de segregação que se aproxima à noção de exílio e que com o passar dos anos sofre, inclusive, uma alteração de signo:

Evidentemente, este tipo de exilio contemporáneo al que nos referimos no puede ser, en consecuencia, idéntico al exilio del pasado. No existe, en nuestro caso, un desplazamiento físico, un cambio de coordenadas espaciales de ningún tipo. Pero acierta Tudoras subrayando la universalidad del sentimiento del exilio. Siendo diferentes por la existencia o no de un desplazamiento, una forma en que podemos redefinirlo es atribuyéndole un nuevo significante. $Y$ éste, siendo «exilio» una palabra de origen latino compuesta por el prefijo «ex-» (fuera) y por 
el verbo "sălío» (saltar), puede ser el «insilio», palabra, por lo demás, que también existe en latín y cuyo significado es «saltar sobre». Sin atender al significado del verbo, pero sí al del prefijo, nuestra propuesta, habida cuenta del desarrollo etimológico del término «exilio», parece que puede tener cierta solidez semántico-lingüística. La única diferencia, pues, del exilio y del insilio sería su desplazamiento físico (Tudela-Fournet, 2020: 83).

Com base em toda essa intricada reorientação, é notável que para além de uma questão física, um deslocamento territorial, há uma série de circunstâncias concernentes ao banimento que não deixam de rondar também seres que permanecem em determinado lugar, sem necessariamente a ele pertencer. É a literatura, por sua força de expressão da condição humana e possibilidade de aprofundamento psicológico, que pode resultar na potência representativa da realidade que também nos permite refletir sobre a noção do exílio.

Dito isso, para contextualizar os marcos temporais em torno da Guerra Civil -antes, durante e depois - e consequente «exílio interior» ou «insílio» é necessário, num primeiro momento, refletir desde o período anterior à contenda, quando bombas começam a ser armadas simbólica e literalmente. Em Ramona, adiós esse momento fica marcado pelos relatos particulares da Mundeta-avó. Apesar de fragmentária, a trama mantém uma sequência narrativa, sempre encabeçada pelo diário da avó e, portanto, pela narração em primeira pessoa. Essa voz, constantemente, transfigura-se em terceira pessoa que passa a focar as vidas da Mundetamãe e Mundeta-filha, em diferentes períodos. Somado a isso, essas distintas vozes constantemente apontam para a questão amorosa das três gerações representadas.

O tom confessional que caracteriza o diário da protagonista mais velha revela ao longo do romance partes de sua vida circunscritas desde um período de finais do século XIX, com o primeiro registro datado de « 6 de diciembre de 1894», em que anuncia o seu casamento: «Pasado mañana me caso con el sobrino de la viuda Climent, Francisco Ventura, que me salvó la noche del Liceo» (Roig, 1992: 43). O último registro de seu diário remonta ao início do século XX, especificado pela data de «2 de enero de 1919»: «Francisco ha muerto esta madrugada. Dios le haya perdonado» (Roig, 1992: 230).

Há, portanto, uma construção narrativa que perpassa sua vida enquanto esposa, mas também demarca acontecimentos históricos ocorridos nesses marcos temporais: o período subsequente ao fim da I Guerra Mundial e à bomba no Gran Teatro del Liceo de Barcelona -este, um atentado dos anarquistas espanhóis a um dos símbolos da oligarquia catalã de finais do século XIX- Com isso, é possível compreender que os registros de Mundeta são feitos ao longo de um tempo de turbulência, não só para a sociedade catalã, mas também europeia. É importante considerar ainda o posicionamento inicial da personagem, pois se Francisco Ventura salvou Mundeta do ataque, é porque, inicialmente, ela fazia parte desse reduto em que estava situada a burguesia catalã, o que se altera gradualmente à medida que as outras gerações de Mundetas são apresentadas. 
O casamento da personagem implica a manutenção de uma classe burguesa decadente e no relato da protagonista vai se revelando a monotonia de uma relação que se abala quando do surgimento de um jovem estudante na vida da mulher:

Las mujeres siempre hemos de comparar. El estudiante de la mirada llameante, de los cabellos rizados como las dos figurillas de mármol, ¿dónde debe de estar? No olvidaré jamás sus ojos sanguíneos, aquella mañana, en el parque de la Ciudadela... Todas las historias, miradas por el lado que se quiera, tienen el mismo final. Somos como animalillos (Roig, 1992: 227).

Em seu registro datado de «6 de diciembre de 1918», passados exatos vinte e quatro anos desde o início de sua escritura do diário, a personagem se situa inicialmente numa posição específica: «Las mujeres siempre hemos de comparar». É ela quem narra e que é central ao longo de toda a obra, composta pelas visões particulares de mulheres sobre seu entorno. A declaração da avó coloca a si mesma e as demais protagonistas como um sujeito distinto, por conta do seu gênero, e aponta para uma constância problemática evidenciada pelo «siempre». A história constantemente contada pelos homens se rompe a partir do gênero diário, essencial para que a perspectiva de uma mulher fique registrada. Seu posicionamento historicamente subalterno é assinalado por meio de sua fé católica, caracterizada pela existência de um ser superior, capaz de controlar o destino dos seres humanos — «como animalillos»-, percebido pela personagem pelo «mismo final» de acordo com a perspectiva que se lança sobre a história de alguém. Logo, de acordo com a declaração de Mundeta, o manejo de uma narrativa se faz essencial para a construção da história. A sua se compõe através da elaboração do passado e sua memória resgata não somente a suposta estabilidade vivida ao longo do seu casamento. A personagem rememora o olhar do estudante com quem manteve um caso amoroso extraconjugal, findado no contato furtivo que marca o último encontro dos dois, antes de ele partir da cidade:

No veía ni los nenúfares ni las aves, tan solo unos tonos negruzcos que destacaban la sombra. Sentían como mis pies se hundían en el barro, cada vez más empapados. La humedad me calaba hasta los huesos, los cabellos se me pegaban a la cara como si fuesen un pañuelo, el agua me resbalaba por el rostro hacia abajo, por el cuello, entraba en mi pecho, sentía mis senos helados y que el frío me había llegado al corazón. Me había quedado inmóvil, clavada en el suelo, las rodillas paralizadas, el cuerpo rígido. No veía nada más que la sombra, la sombra que se acercaba cada vez más definida, más exacta, con los ojos salidos, sanguíneos. Y sentí una masa que me caía encima, que me apretaba la cintura, que metía su mano dentro de mi vestido... (Roig, 1992: 201).

A visão, como elemento sensorial característico da memória, marca as lembranças da Mundeta-avó quando envelhecida, que recorda justamente o olhar do estudante com quem se envolveu. Ela registra no dia «18 de junio de 1901» seu percurso até ir ao encontro dele, mas nesse caminho percorrido no passado até o «parque de la Ciudadela», onde ele a espera, sua visão fica embaçada. Tons «negruzcos» se destacam na sombra que ambienta seu trajeto e simbolizam um aspecto próprio da memória: ela não se constrói de maneira clara e exata, mas por meio de imprecisões e fragmentos intensificados pela sensação da personagem, mulher e católica, que está prestes a cometer um delito —um pecado de acordo com seus dogmas-. Ao longo do seu caminho, a chuva se faz presente e 
umedece o espaço que percorre, embaçando, inclusive, a visão dela. As manifestações da natureza se deslocam do exterior para o interior da personagem, ou ainda, conformam a perspectiva dela sobre 0 acontecimento narrado: o frio adentra seu corpo e chega ao seu coração; a sombra que abarca o ambiente é também a que circunda o corpo do jovem que a espera; a umidade do ar a mantém, a princípio, estática: «quedarse inmóvil», «clavada» e «paralizada», com o corpo «rígido» assinalam as dificuldades de uma mulher historicamente estática, coagida, que transpõe as barreiras de sua própria consciência para executar um ato transgressor. Ela, fundida no barro -elemento de criação do homem, de acordo com a perspectiva cristã - deve realizar o esforço de se mover dessa sua posição de criatura para, enfim, poder ser aquela que realiza e protagoniza sua própria história, alcançando no contato com seu amante, a realização do seu desejo -marcado também pela intensa umidade do ar que vai tomando conta de todo o seu corpo à medida que ela se aproxima do homem por quem sente atração sexual.

Essa relação furtiva, no entanto, não ocasiona uma ruptura de Mundeta com o seu modo de vida, mas implica o silenciamento marcado em seus relatos. Após o encontro derradeiro com o estudante, há um grande lapso em seus registros que aponta para o sufocamento da protagonista que deixa de se expressar como de costume. Ela só volta a fazer um registro em seu diário anos mais tarde, em «9 de junio de 1909», já quando havia «tenido la niña» (Roig, 1992: 209).

\section{Explosões}

O caráter não linear da narrativa forma o todo da obra, iniciada pelo prólogo e encerrada pelo posfácio registrados em itálico, que situa a segunda geração das Ramonas já no período da Guerra Civil Espanhola. O romance se inicia com o relato da Mundeta-mãe que está à procura do marido durante um momento caótico de sua vida: sua busca pelo marido após a explosão de bombas na cidade de Barcelona. Em seu relato, se destacam três personagens: ele, Joan, que foi a San Sebastián saber sobre o andamento da guerra; a mãe, Mundeta, que estava em Siurana no momento das explosões, considerava-se republicana, ao passo que gostava do rei, mas não dos anarquistas; e a amiga Kati, caracterizada como uma mulher forte e independente: «todas abrigaban una secreta envidia hacia Kati. Tenía treinta años, era soltera y vivía sola» (86).

Desde o início, se nota que a protagonista em seu relato traz à tona personagens e situações por meio da associação de ideias que vão se somando ao longo do texto e, por vezes, também se ramificam, dilatando -ainda que para pontos divergentes - o ponto de vista. Tanto o olhar da Mundeta-avó quanto o da Mundeta-mãe iniciam-se pela referência a explosão de uma bomba sobre a cidade. Dessa maneira, é possível considerar que tais explosões simbolizam a própria construção de uma narrativa fragmentária, constituída a partir dos destroços ocasionados pelos bombardeios. Os estilhaços que se espalham sobre a cidade são realinhados pela memória de três mulheres e a soma dessas ideias dá um 
parâmetro geral, ainda que repleto de rupturas, sobre a conjuntura da guerra:

Cuando supe que había estallado un camión de trilita en el bombardeo de la mañana, me asusté mucho. Yo ya sospechaba que pasaban cosas graves porque los cristales de la galería se hicieron añicos y desde entonces las sirenas no han parado. Salí a la calle como una loca y no sabía adónde ir. Pasé dos horas alrededor del Coliseum, de un lado para otro, pero había una muchedumbre de soldados que lo rodeaban y nos hacían circular. Mis piernas apenas me sostenían y no me atrevía a preguntar si alguien sabía el nombre de los muertos. Un viejo lleno de llagas y con la cara muy arrugada y sucia me tocó. Salí corriendo de la aprensión que me dio. Caminaba por las calles desorientada. Desde que estalló la guerra había salido pocas veces sola de la casa. O bien iba con mamá o con Joan si él tenía tiempo. Me horrorizaba ver Barcelona llena de escombros, de basuras en estado de putrefacción. Todo hedía a huevos podridos y a cal hervida. Había muchas casas hundidas y de entre las ruinas salían sillas, mesas, a veces cunas y muñecas de trapo. A mí las ruinas siempre me han dado mucha lástima. Cuando íbamos de excursión a algún castillo, como el de Burriac $o$ el de Tona, y contemplaba las cuatro paredes desamparadas, se me saltaban las lágrimas sin que pudiera evitarlo. Joan me decía que era una ñoña, que un montón de piedras no hacen llorar a nadie, que si me habían sorbido el seso. Y mamá me defendía, déjala, le decía, que es tan romántica como yo (Roig, 1992: 16).

Tal como Mundeta-avó que percorria o caminho até o encontro de um seu caso amoroso, Mundeta-mãe está na rua à procura do marido. Seu posicionamento em espaço aberto, contudo, não simboliza liberdade, mas sim desorientação. Esta noção fica marcada desde o início do romance que, in media res, apresenta uma personagem atordoada por sua busca. $\mathrm{Na}$ continuação da obra, não há uma sequência cronológica dos fatos, mas uma variação constante do foco narrativo. Portanto, diferentes vozes se conjugam e apontam para um parâmetro geral, repleto de rupturas, sobre os distintos tempos ficcionalizados -0 que, ressalto, implica o caráter polifônico da trama.

Através da perspectiva da Mundeta-mãe, mobilizam-se uma série de termos relacionados com a explosão («estalló»; "escombros»; «basura», «putrefacción»; «podridos»; «hundidas»; «ruinas»). A personagem está confusa ao caminhar pela rua, o que fica plasmado nos muitos períodos que compõem o parágrafo e todo o prefácio. Espaço e tempo estão em ruínas. É tempo de guerra num espaço de devastação:

Barcelona tenía para mí un color insólito, mis ojos iban descubriendo un espectáculo desconocido, de gente, de movimiento, era como si fuese en otra ciudad. En el tranvía oí a un hombre mayor decir que los aviones habían bombardeado los puntos más céntricos y de una manera muy minuciosa [...]. Las bombas eran de gran potencia y habían sido lanzadas desde una altitud mínima de 5.200 metros. Desde semejante altitud aún no comprendo cómo no revienta la ciudad entera, sería mejor para todos nosotros, dijo el anciano, y entonces le miré más de cerca y vi que tenía la cara picada (Roig, 1992: 24).

O período da contenda demarca a forma como espaço e tempo se compõem na trama, pela ideia de movimento e mudança. Isso se intensifica pela própria posição da personagem que está dentro do bonde e ouve comentários de outras pessoas sobre os bombardeios. Para uma delas, o desejo é de que toda a cidade se arrebente com as bombas lançadas pelo avião. Literal e metaforicamente é o que acontece: Barcelona está arrasada 
pelas explosões que convertem a cidade num amontoado de destroços. $E$ as ruínas são marcas indeléveis para todos os que estão imersos na situação de guerra, posto que suas vidas estarão marcadas peremptoriamente pelas consequências físicas e psicológicas que avassalam o espaço. Essa conjuntura é delineada, precisamente, pelos efeitos sinestésicos plasmados ao longo da trama. Além da própria audição da personagem-narradora, outro dos seus sentidos é de fundamental importância: a visão. Através do seu olhar, o «colorido da memória» assume um matiz distinto que é concedido ao lugar percorrido por ela. De dentro do bonde, ela enxerga uma cidade de cor insólita, e sua visão passa a descobrir e ir revelando por meio da narrativa outros tons que encobrem o espaço, construindo, assim, uma paisagem. Nesse caso, especificamente, sobressai o tom monocromático, característico das cinzas dos escombros que tomam conta da cidade. Prenuncia-se a problemática da vida de Mundeta, situada num tempo-espaço de caos. Fica, portanto, plasmada nas linhas do romance a destruição urbana que, tal como Guernica, possibilita «traducir en términos del arte el choque violento de la guerra que se consignaba cada día en los medios gráficos de comunicación masiva» havendo um diálogo «en su monocromía, con la fotografía periodística» (Miranda, 2016). Isso, por sua vez, permite-me considerar a escritura narrativa também como uma forma de se contar a história, no entanto, por meio da ideia de representação dos escombros de um passado composto ficcionalmente.

\section{Estilhaços}

No romance, a desorientação que demarca o rumo das personagens assume amplitude, ao se caracterizar como um dos grandes desastres da guerra: não há vencedores, mas um confuso caminhar por entre os destroços que se amontoam ao longo da cidade e se perpetuam como consequência da guerra. Neste contexto é que está inserida a terceira geração das Ramonas. A Mundeta-filha desenvolve sua perspectiva enquanto geração nascida durante a contenda. Sua juventude, portanto, está marcada pelo período de exceção decorrente da vitória dos nacionalistas que impuseram o regime ditatorial no país. Logo, ela conhece o passado bélico por meio dos relatos contínuos que escuta da mãe: «a guerra era contada de mil maneiras distintas, e a diferença entre uma e outra provinha da forma peculiaríssima e «única» em que cada um a tinha vivida». Novamente fica indicada a ideia da construção do passado e da história, feita exclusivamente pela perspectiva de quem conta e pela maneira como isso se realiza. Se para a avó é possível compreender a história dos sujeitos de maneira unívoca, como uma fatalidade do destino, para a neta, a repetição do passado implica também a sua reconstrução, já que sempre ao ser recontado ele assume novos matizes.

Nesse sentido, a noção estática sobre a mulher que se compõe com a narrativa da avó, vai se rompendo na medida em que mãe e filha seguem percursos relativamente mais autônomos e menos subalternos a cada mudança de geração. Em outras palavras, o passo do tempo transfigura a posição e a perspectiva da mulher representada por cada uma das Ramonas. A mais nova transpõe a imobilidade que marca suas 
antepassadas e se atenua com os anos e seu cotidiano fica marcado por uma maior emancipação, indo de encontro à conjuntura em que vive. A Mundeta-filha vivencia uma tensão constante com Jordi, um de seus companheiros de curso. Ambos são estudantes universitários engajados em questões políticas e a busca pela liberdade comum também se transpõe nas individualidades da relação que mantêm. Vivem o amor livre em seu relacionamento, mas isso também acarreta a desorientação de Mundeta que, após um dos desentendimentos com Jordi ao vê-lo com a amiga Anna, decide se prostituir. A ação de Mundeta, no entanto, revela que seu interesse não está em arrecadar dinheiro em troca de uma relação sexual, mas como ela mesma pensa: «hay que pasar por todas las experiencias, ésta es tan buena como cualquier otra. Si Anna era una puta, por qué no ella» (Roig, 1992: 150). Após vivenciar essa nova experiência durante a madrugada, volta a estar sozinha na rua durante o amanhecer:

\begin{abstract}
La noche se confundía con las primeras claridades que anunciaban el alba. Caía una llovizna y se oía el chapoteo de unos pasos. Se veía una niebla baja que descendía por la ladera del Tibidabo. El amanecer se estiraba en escamas grisáceas. Ahora la ciudad era más silenciosa que antes. El hombre del «Alpine» la dejó en la esquina de su casa y el coche, seguro, veloz, potente, cogió la calle Aribau hacia arriba. El ruido del motor se fue amortiguando en la penumbra. Aquí paz y allá gloria, pensó. Cogió los dos billetes y, lentamente, los rompió. El aire fresco de la madrugada la había despejado del todo. Respiró hondo. Cuando dos se aman, Mundeta, se llevan pedazos de recuerdo el uno del otro. Pedazos, pensó, mientras veía los trozos de papel arrugado que caían en un charco, pedazos de recuerdo (Roig, 1992: 154).
\end{abstract}

É a partir do que viveu durante a relação sexual com um desconhecido, e após sentir ciúmes do companheiro e da amiga, que Mundeta lança seu olhar sobre a cidade e começa a delineá-la. O entorno tensiona entre a escuridão e a claridade e a umidade do ar resulta numa paisagem acinzentada e com névoa. Junto a isso, ela é deixada pelo homem com quem passou a noite na esquina da sua casa, outra indicação espacial que assinala um posicionamento intermediário entre dois caminhos. A tensão que se evidencia na conformação do espaço se configura também no pensamento de Mundeda ao observar o carro do homem se afastar. A penumbra do lugar é atravessada por uma máquina caracterizada por sua segurança, velocidade e potência, que culminam na glória do sujeito que está «allá». Por outro lado, ela está situada numa posição de paz, na qual nenhuma das características do carro se fazem presentes, pois o silêncio toma conta do espaço após a partida da máquina. Essa dualidade entre claro e escuro e presença/ruído do carro e distanciamento/silêncio dele apontam para uma problemática da geração mais nova das Mundetas, relacionada com o embate entre a memória e o esquecimento.

A protagonista reflete sobre as partes de si mesma que permanecem com o outro que ama, bem como nas partes dele que continuam com ela por meio da construção da memória. Estão simbolizadas pelas notas de dinheiro que ela recebe do homem. Ele paga por um momento de aproximação física com ela, na busca pela satisfação do seu desejo. Ela, por sua vez, rejeita o dinheiro recebido, indicando em seu gesto a incompatibilidade de se aliar o capital com a realização do desejo. Não obstante, os pedaços das notas também indicam os pedaços de recordação, as lembranças amorosas por ela vivida. É nessa relação entre 
lembrança e vil metal que fica assinalada uma nova forma de composição da memória: a partir da constituição monetária. Se antes, quando avó e mãe estiveram pelas ruas, os fragmentos se constituíam como consequência dos bombardeios, agora, no momento em que a filha está na rua, a fragmentação é também resultante dos pedaços de papel que assumem valor comercial e movimentam a sociedade.

Com o passo dos anos e o recrudescimento do autoritarismo, Barcelona deixa de ser alvo de bombas e passa a ser reconstruída, precisamente pelo dinheiro capaz de reconstruir a cidade outrora devastada. Junto a essa reconstrução, no entanto, o que se põe em xeque é a memória sobre as consequências do período bélico, posto que 0 desenvolvimento socioeconômico mascara um passado de ruínas abafado pelo esquecimento propagado principalmente às novas gerações que não vivenciaram diretamente a contenda. A ela, outros elementos são oferecidos como suporte para um novo cotidiano, caracterizado por um suposto desenvolvimento:

\begin{abstract}
En el mercado aparecían, dinámicos, veloces, confortables y seguros, los nuevos automóviles. Fidelidad al slogan, la inversión es el motor de la economía. Se multiplicaban los parkings subterráneos. Los coches reducían la velocidad. Faltaba espacio. Polémicas, para los iniciados, sobre las zonas verdes que estafaban al ciudadano. Barcelona de finales de los sesenta, diversa y eclética, llena de tópicos que servían para engolosinar con imágenes gratuitas a quienes cultivaban la literatura gris, de oficina, carente de nervio e imaginación (Roig, 1992: 224).
\end{abstract}

Não há um revisionismo histórico sobre os desastres da Guerra Civil Espanhola. Não somente no fim dos anos de 1960, mas também a partir da transição democrática iniciada após a morte do ditador, em 1975. À medida que a truculência ditatorial se atenua, o país abre suas portas, não para as centenas de vítimas expatriadas por conta de seu posicionamento político, mas aos turistas do mundo e seu poder de compra, capaz de movimentar a economia do país.

O que o olhar de Mundeta capta é também figuração das bombas que outrora foram lançadas sobre a cidade. Os estilhaços ficam sob um espaço reconstruído pela lógica do mercado. Constrói-se uma suposta sensação de segurança e estabilidade marcadas na adjetivação dos automóveis «dinámicos, veloces, confortables y seguros»-. Há um aumento no consumo e poder de aquisição populacional que interferem diretamente na constituição espacial da cidade. Simbolicamente, os estacionamentos subterrâneos indicam um tempo presente superficial, enclausurado pela falta de espaço decorrente do contingente automobilístico. O passado atroz é encoberto e soterrado pela propaganda desenvolvimentista que se faz presente, mas é nos subterrâneos que se escondem as tragédias vividas outrora. O olhar da protagonista capta com ironia a diversidade que se alastra, ao passo que a imaginação —ponto de passagem e composição da memória- se reduz a formas restritivas de discurso que passam a conformar o cotidiano de um país sufocado pelo autoritarismo consequente da guerra. 


\section{Considerações finais}

Com a transposição cronotópica também se modifica a geração de Mundetas. Na cena em que avó, mãe e filha se encontram, evidencia-se a mudança desta última: "Mundeta, cómo has cambiado...» (Roig, 1992:199). A mulher catalã de fins do século XIX, moldada a partir dos preceitos católicos, está envelhecida, ao passo que a jovem esposa que busca pelo seu marido em meio aos bombardeios do confronto bélico dos anos de 1930 também envelhece. A desorientação de ambas, no entanto, permanece naquela que representa uma nova geração, mas que também está marcada pelas amarras sociais que se perpetuam em seu entorno. A Mundeta-filha já não mais representa uma mulher restringida pelos dogmas da fé ou marcada pelos estilhaços de bombas da guerra. A cidade que ela percebe, no entanto, é a constituição desses estilhaços em forma discursiva que, no movimento e aumento do número de automóveis pelas ruas e nas notas de dinheiro que ela rasga e atira ao chão, assinalam a fragmentação de um passado atroz que reverbera no sufocamento do tempo presente, superficialmente melhorado, mas sem espaço suficiente para abrigar sujeitos que permanecem exilados dentro da cidade.

Esse processo «insiliar», portanto, ocorre por meio do ensimesmamento de toda uma geração de mulheres cerceadas por uma sociedade patriarcal e autoritária (ainda que tais adjetivações, postas lado a lado, possam indicar certa redundância). A posição no ângulo doméstico das personagens delineadas por Montserrat Roig, em seu primeiro romance, não correspondem literalmente a uma segregação territorial, não obstante, a ambiência composta por meio das mulheres de ficção e do espaço onde elas tortuosamente circulam possibilitam refletir sobre o processo de exílio consequente da Guerra Civil Espanhola enquanto contraponto aos que ultrapassaram a fronteira do país ou, ainda, justamente pela confluência dos efeitos para os que se foram e para os que permaneceram reprimidos direta e indiretamente em seu próprio país.

\section{Bibliografia citada}

BEEVOR, A. (2007): A batalha pela Espanha. A Guerra Civil Espanhola. 19361939. Trad. Maria Beatriz de Medina, Rio de Janeiro: Record.

COLLOT, M (2012): «Rumo a uma geografia literária», Gragoatá, 33, 17-31.

DANNER, L. F. (2013): Temas de Filosofia Política Contemporânea, Porto Alegre:

Fi.

ETTE, O (2015): «Em direção a uma poética do movimento: literaturas sem residência fixa» in Literaturas em trânsito, teorias peregrinas, Curitiba: Ed. UFPR. GRACIA, J. e RUIZ CARNICER, M. Á. (2004): La España de Franco (1939-1975). Cultura y vida cotidiana, Madrid: Síntesis.

LEVI, P. (2013): Si esto es un hombre. Trad. Pilar Gómez Bedate, Barcelona: Austral.

MARTIN GAITE, C. (1994): Usos amorosos en la posguerra española, Barcelona: Anagrama.

MIRANDA, J. (2016): Frenética armonía: vanguardias poéticas latinoamericanas en la Guerra Civil Espanhola, Rosário: Beatriz Viterbo Editora.

RICOEUR, P. (2007): A memória, a história, o esquecimento. Trad. Alain François, Campinas: Editora da Unicamp. 
ROIG, M. (1992): Ramona, adiós, Barcelona: Plaza y Janés.

ROIG M. (2017): Los catalanes en los campos nazis, Barcelona: Península.

SALABERT, M. (1988): El exilio interior, Barcelona: Anthropos.

TUDELA-FOURNET, M (2020): «Insilio: formas y significados contemporáneos del exilio», Pensamiento, vol. 76, 288, 75-87.

VILAR, P. (1986): La guerra civil española, Barcelona: Crítica.

\footnotetext{
${ }^{1}$ Somente nos sessenta é que a presença do catalão retoma de modo mais normalizado as manifestações discursivas, para tanto, há um proceso de divulgação no qual a literatura e os meios de comunicação são de fundamental importância: «La lengua catalana aspira a acceder a un nivel de divulgación y uso como el que disfrutó al menos durante buena parte del primer tercio de siglo —cuando la prensa catalana, por ejemplo, era tan variada, numerosa y de calidad como la escrita en español, al igual que sucede con las revistas culturales en Galicia o la misma Cataluña - y de momento solo sueña con la posibilidad de que la vida oficial y pública pueda desarrollarse en una lengua que no es un patois, ni un dialecto sino una de las dos lenguas de uso civil y cultural de gran parte de la población» (Gracia e Ruiz Carnicer, 2004).

2 Esse estudo de Carmen Martín Gaite se centra na análise da vida da mulher espanhola, do imediato pós-guerra até metade da década de 1950, e no modo como ela era vista pela sociedade da época. Discute-se a imagem heterogênea da mulher que era transmitida à juventude: «junto a la abuela con devocionario y matilla de toda la vida, aparecían otra clase de mujeres, desde la miliciana hasta la vamp, pasando por la investigadora que sale con una beca al extranjero y la que da mítines» (Martín Gaite, 1994).
} 